\title{
The Russian Premiere of Claudel's L'Échange
}

\author{
Keith Tribble \\ Oklahoma State University, Stillwater
}

The Russian stage premiere of Paul Claudel's L'Échange under the title "Obmen" took place on 20 February 1918 at the Kamerny Teatr (Chamber Theater) in Moscow. ${ }^{1}$ It was the first full-length play presented by the theater since the Communist Revolution. The production was designed by Georgy Yakulov (1884-1928) and directed by Vsevolod Meierkhold (1874-1940) and Aleksandr Tairov (1885-1950). The production was Yakulov's first effort as a set designer and the only time Meierkhold and Tairov ever collaborated on any effort. The part of Louis Laine was played by B. A. Ferdinandov, Marthe by N.E. Kollen, Thomas Pollock by K. V. Eggert and Lechy Elbernon by N. V. Komarovskaia. The translation by Evgeny Pann and Liudmila Vilkina was written in Paris in 1913.

It appears initially strange that the work of a deeply religious, monarchist, symbolist poet should serve as a vehicle for the inauguration of the Soviet stage. But to understand why this happened it is necessary to look back over the decade of theatrical experiment and controversy that preceded the Russian stage premiere of Claudel. It is noteworthy that many dramatists, poets, and directors who had shown a considerable interest in Claudel's work in the decade preceding the revolution did not emigrate but rather became key figures in the Soviet cultural firmament. ${ }^{2}$ One of the most singular instances is the case of the Anatoly Lunacharsky, the first Commissar of the Enlightenment of the new Soviet state. ${ }^{3}$ In the decade preceding the revolution like a great many figures of his generation Lunacharsky went through a period of god-seeking ("Bogoiskatelstvo", as the Russians very frequently referred to it) which involved infatuation with the works of Claudel. Lunacharsky translated Claudel's L'Otage [The Hostage], but unfortunately the translation has not been preserved. Lunacharsky was present at the premiere of The Exchange at the Théâtre du Vieux Colombier in 1914, an event he reviewed on the pages of the newspaper Kievan Thought. In his review entitled "Mystical Tragicomedy" Lunacharsky speculated that The Exchange was written as Claudel's 


\section{Keith Tribble}

repentance for having been tempted by the American atmosphere of easy money-making and free sexual relations ${ }^{4}$.

The most prominent stage director to evidence interest in Claudel in the decade preceding the revolution was Vsevolod Meierkhold ${ }^{5}$, most frequently associated today with constructivist experiments in the first decade of the Soviet stage, with the theory of biomechanics in acting, and for his identification with such icons of Soviet culture as Vladimir Maiakovsky whose often propagandistic works Meierkhold staged. However, Meierkhold had developed his craft through a long series of experiments with both Western European and Russian symbolist dramas. Throughout his writings we find scattered references to a variety of works of this repertory which he hoped and planned to stage, including the plays of Claudel. In the early 1910s Claudel figures in manuscript notes of Meierkhold for a bibliography of modern drama. ${ }^{6}$ In the journal Love for Three Oranges that Meierkhold edited in 1914 there is a note that students in Meierkhold's studio were to become familiar with representative works of the modern repertory that had been rejected by the establishment including the works of Claudel. Meierkhold participated in the planning of a Saint Petersburg cabaret theater which was eventually called the Comedians' Halt but was initially announced as the Theater of Underground Classics; the repertory was supposed to include Claudel. ${ }^{7}$

According to an unpublished note by the theater historian Aleksandr Vasil'evich Fevralsky dated 9 June, 1939, K.I. Deizerman translated The Exchange and passed the text of his translation on to Meierkhold in Paris in $1913^{8}$. However, this text was never published and the manuscript has not survived; it was never used for production of the play. Also in the audience at the Paris premiere of The Exchange was the young translator and critic Evgeny Pann. Six months before Jacques Copeau had unveiled the first production of The Exchange Pann wrote to Meierkhold this previously unpublished letter:

Paris 28 August 1913

Deeply respected Vsevolod Emilievich:

During our chat at the Hôtel d'léna in Paris you asked me to send you my projected translation of Claudel's drama The Exchange. At the present time Mrs. Vilkina and I have finished this translation and I am 
sending it to you. After reading [it] just let me know whether this [play] might be accepted for performance by the direction of the Imperial Theaters.

Sincerely devoted

E. Pann

Paris, 8 Rue Marie-Rose

P.S. I have special permission from Plon for performance of this play in Russia.

E.P.

Meierkhold was at this time the director of the Imperial Theaters in St. Petersburg. With this status came the royal subsidy, prestige and consequently greater visibility toward which Pann aspired, as can be seen from this and his next letter. The collaborator to whom Pann refers, Liudmila Vilkina, the wife of the symbolist poet Nikolai Minsky, was a prolific translator; she remained in Paris where she died in 1920. Vilkina is best remembered as translator of the collected works of Maurice Maeterlinck which appeared in three volumes in Russian in the first decade of the century. ${ }^{9}$ Vilkina translated the first two acts of The Echange and Pann the last act.

Meierkhold's letter of response to Pann has not been preserved. A month later Pann wrote to Meierkhold again:

Paris 16 September 1913

Deeply respected Vsevolod Emilievich,

I of course have nothing against your suggesting Claudel's play to the directors of Petersburg theaters, if it won't work out for the Imperial Theater.

But why not use in the case of The Exchange your right to stage one play at the Imperial Theater. In truth you would not regret it, this production would bring you great success. I would like to believe this and rejoice in it. 
P.S. They call me Isidorovich and with great happiness. It would make me happy if this (in my opinion greatest achievement of symbolism) were to have its first embodiment on the stage at the deft hands of the creator of the theater of conventions. This would incorporate symbolism, a synthesis of the coming meeting of Slavic and Gallic genius, a meeting promising the world unforeseen ecstasies of art. I joyfully and gratefully accept your proposition that I write you often; there is so much good that can be accomplished for the art of the stage by bringing Paris and Petersburg closer together. ${ }^{10}$

The allusion to the theater of conventions referring to the theatrical style Meierkhold created for productions of symbolist dramas in the first decade of the century was meant to suggest any theater opposed to naturalism and celebrating theatricality.

The first published announcement about the Russian translation of The Exchange appeared in March 1914 in the journal Writers' Diaries edited by the poet Fyodor Sologub where Vilkina was listed as the translator. ${ }^{11}$ Meierkhold soon read this translation to a group in Petersburg, as we learn from the following letter addressed to Meierkhold in December 1914 by the symbolist poet and critic Georgy Chulkov ${ }^{12}$ :

I read all of your Claudel's books. By the way, when I read L'Echange in French, I liked this piece a lot. Apparently I wasn't hearing well when you read it to us, or else the translation was not successful. ${ }^{13}$

Evgeny Pann, the co-translator of The Exchange, published two essays in 1914 about Claudel in which he comments on this as well as others of Claudel's plays. In the essay "The Drama of Eternity in Claudel's Works" he suggests as the essential message of the drama not betraying one's own divine nature ${ }^{14}$. In the essay "In Defense of Expressive Art (A Letter from Paris)" Pann quotes Lechy Elbernon's words about the theater as Claudel's theatrical credo and defines Claudel's conception of the theater as a temple to which man, tired of ignorance, brings his worry and sorrow, while the priest of this theater absorbs the joy, grief and uneasiness of the spectators and weaves them into his own imaginative dream tale. ${ }^{15}$ 
The text of the translation of The Exchange by Vilkina and Pann has been preserved in the archive of Tairov's Chamber Theater at the Russian State Archive of Literature and Art in Moscow. ${ }^{16}$ It is a 163-page typescript with many emendations in pen and large portions crossed out. This makes it clear that although they translated the entire text of the drama, Tairov subsequently made heavy cuts in the text, as he was later to do in his 1920 production of Claudel's The Tidings Brought to Mary. There does not appear to be any ideological motivation for the cuts, which simply entail condensing long descriptions, repetitions, flights of rhetoric. Also Claudel's frequent interpolations in idiosyncratic English are excised by the translators. The acting text tends to skip passages full of abstraction and generalization such as Louis Laine's comments on Marthe's Intelligence at the beginning of Act Two. Vilkina showed some hesitancy in translating the key concepts of "prix" and "valeur" in the first act. In the scene with Thomas Pollock Nageoire in the first act the Russian word "stoimost" (cost) is crossed out and replaced with "tsena" (value). There is a second typescript of the play at the library of the All-Russian Theater Society in Moscow. It is much shorter than the text in Tairov's archive and must be closer to the acting version actually used ${ }^{17}$. I have compared parts of this typescript with the typescript in Tairov's archive, but apart from condensation of the text for reasons of length, the comparison revealed no interesting variants. Neither of these versions was ever published. Although the translation of The Exchange by Vilkina and Pann remains the only complete version of Claudel's drama in Russian, it is worth noting in passing that Andrei Levinson, who later became a professor at the University of Paris and was known in the West principally for his critiques of the ballet ${ }^{18}$, did translate an excerpt from The Exchange (which Levinson entitles Mena), namely Lechy Elbernon's hymn to the theater, which appeared in the Petersburg newspaper The Life of Art in November 1918, ten months after the play's premiere at Tairov's theater in Moscow. ${ }^{19}$

After the Revolution Meierkhold continued to express interest in Claudel's work by negotiating (unsuccessfully) with the poetess Marina Tsvetaeva about a translation of Tête d'or and by allowing his futurist collaborator Ivan Aksenov to stage a production of his own translationadaptation of Claudel's Coufontaine trilogy under the title the Tiara veka (The Tiara of the Century). But the only time Meierkhold actually participated in staging a work by Claudel was the 1918 production of The Echange which premiered in February 1918 only four months after the revolution. 


\section{Keith Tribble}

The choice of the drama The Exchange might be thought to have been ideologically motivated. At first glance it would appear that of all of Claudel's works, the one that depicted America critically as a materialistic state in which financial transactions conducted by millionaire magnates played a determining role in the moral life of poor people, would have corresponded best to the spirit of the nascent Marxist state. However, there is in fact no scrap of evidence in the writings of those involved in the production, nor in the critical comment about it to support such an ideologically determined view. Indeed, the production was rejected outright as out of touch with the spirit of the times in Russia. The drama appears to have been chosen because there was a dearth of new Russian plays and translations of new Western plays. By the time of the Communist Revolution Symbolism in Russia had run its course, although many of its key works had never even been produced. Claudel was of interest, not as representative of European symbolism and certainly not as a sign of a Catholic renaissance in France, but simply because his work had attracted relatively recent attention on the stage of Jacques Copeau's Vieux Colombier and had not to date been produced in Russia.

The actress Alisa Koonen, who was the wife of Aleksandr Tairovfounder and director of the Kamerny Teatr (Chamber Theater) - and who two years later would portray Violaine in the Russian premiere of Claudel's The Tidings Brought to Mary, tells in her autobiography about the events that brought Tairov and Meierkhold together in 1918:

When Meierkhold came to Moscow from Petrograd, he had no theater and Tairov proposed to him and to Evreinov that they create a common "leftist" theater, in which each one of them would work quite independently. Negotiations about this went on for a long time and led to nothing. But Tairov and Meierkhold did stage one production together-Claudel's The Exchange. As it transpired, the production was unsuccessful. When I saw the dress rehearsal, it seemed to me that both the directors and the remarkable set designer Yakulov had lost their way in this play. I was astonished by the complete lack of coordination between the various elements of the production. The Exchange ran for a short time and was soon dropped from the repertory. ${ }^{20}$ 
Vsevolod Meierkhold participated in the first premiere of 1918 at Tairov's Kamerny Theater (The Chamber Theater) principally by helping the Tairov devise a director's plan for staging the work. Preparations for the production had begun before the Communist Revolution during the interim regime of Kerensky. The choice of the play and the style of production were entirely Meierkhold's: "I have devised the basic principle of the whole plan," he wrote to Tairov in early December 1917. "I have thought out the essential tone of the production and found an ingenious trick for the action [...] I will come three or four days before the first dress rehearsal [...] As for the poster advertising Claudel's The Exchange, put two names: production by masters V.E. Meierkhold and A. Ia. Tairov". ${ }^{21}$ In September 1917 Meierkhold had written to Tairov asking him not to be angry, but explaining that the translation of The Exchange was still being rewritten..$^{22}$ The actual work with the actors seems to have been conducted by Tairov himself although the program gives Meierkhold credit as codirector. In this production Tairov decisively rejected realistically depictive stage sets; in fact The Exchange was enacted on an almost bare stage ${ }^{23}$.

In reaction against the symbolists and iconoclastically against almost all of Western culture Russian futurism, which had been influenced by the theories of the Italian futurist Marinetti and bears comparison with some works of dadaism and surrealism in France, reached the cultural foreground at the middle of the second decade of the century. Most of the prominent futurist creators (artists and poets) accepted the revolution ecstatically and remained in the Soviet Russian, while many of the symbolists had emigrated. Literary Futurism was dominated by images drawn from different planes of existence, juxtaposed to create a new dimension, by extreme emphasis on the phonic value of speech (sometimes called trans-sense language) and, ideologically, by a revolt against everything that had previously transpired in European literature. In artistic terms futurism coincides to a large extent with constructivism, the aspiration to reduce form to basic geometic shapes and to invoke an architectural principle in sculpture, painting and set design. This is obviously an improbable setting for the introduction of Claudel into the Russian theater. Nevertheless from the time of the revolution and continuing into the 1930s those in Russia who were interested in Claudel were almost all involved to a greater or lesser extent in the futurist movement. This is evidenced by three stage productions (Aksenov's adaptation of the Coufontaine cycle on a 
constructivist stage at Meierkhold's studio, Vesnin's production The Tidings Brought to Mary for Tairov's Kamerny theater in 1920 and the 1918 production of The Exchange), as well as by translations of Claudel's poetry by the futurist poet Benedikt Livshitz who was executed in 1938 as part of a homosexual pogrom. The imaginists ${ }^{24}$ and constructivists shared a concern with creation of three-dimensionality in theatrical space and in words. ${ }^{25}$ The imaginist poet Vadim Shershenevich who translated The Tidings Brought to Mary for Tairov in 1920 also translated the theory of free verse by Charles Vildrac and Georges Duhamel that same year. ${ }^{26}$ In his memoirs he recalls that "during the period of imaginism a battle for primacy ensued between Tairov and Meierkhold. Now this struggle as been resolved. It was then at its peak. I worked with Tairov at the Chamber Theater. Then we split and I became close to Meierkhold. Now I am in fine relations with Tairov and scarcely nod at Meierkhold. The imaginists took part in the struggle." 27

Meierkhold's correspondence with Tairov makes it clear that it was Meierkhold who chose to involve the futurist painter Goergy Yakulov in the production of The Exchange. Around October or November of 1917 Meierkhold wrote to Tairov again from Petrograd:

I am sending you The Exchange together with directions for staging it, but I request that you send me the dimensions of the stage immediately upon receiving this letter: 1) the width of the footlights, depth from the footlights to the furthest line of the rear stage and the height of the stage; 2) is there a proscenium; 3 ) if there is no prosceniium, what occupies the space between the first row of the parterre seats and the stage? (an orchestra?); 4) the position of the spectators' seats (parterre, where are the loges); 5) from what seats is visibility poor; 6) what is the lighting mechanism; 7) are there footlights?; 8) what sort of curtain is there opening from the center or rising.

I would like to entrust The Exchange to Yakulov.

As soon as I have received a point-by-point answer to my inquiry from you about the stage set-up, I will imme- 
diately set to work on a preliminary staging plan (before talking with the set designer), then I will ask Yakulov to come here for a day or two. ${ }^{28}$

This letter makes it clear that Tairov was delivered a directorial faite accomplie by Meierkhold which would in the long run shackle his work on Claudel's drama to its ultimate detriment. It also suggests that Meierkhold's interest in the work was essentially formal, structural and on the surface-features which would later be painfully evident to the critics.

The theatrical essence of Georgy Bogdanovich Yakulov (18841928) was a life-loving sense of spectacle and a romantic exultation in the harlequinade. When Yakulov came to the Chamber Theater in 1918, he was already a well-known painter, graphic artist with limited but promising experience as a decorative artist. The Exchange constituted his debut as a set designer. For Claudel's play Yakulov designed a laconic, ascetic, transparent constructivist set..$^{29}$ Its dry, simplified forms, distilled to the point of schematicism, did not mesh well the multifaceted work being staged. The stage spage was filled with the outlines of objects. The forms of objects were abstracted and crystallized to such a degree that the stage appeared rung out, bloodless and lifeless. Nevertheless it went down in history as the first constructivist production in the history of the Chamber Theater.

Among the unpublished notes by theater historian Aleksandr Vasil'evich Fevral'sky who was later to edit the letters and speeches of Tairov there is a brief note about the production of The Exchange taken from Meierkhold's own words in 1936:

Georgy A. Krol ${ }^{30}$ at first wanted to work in the [cabaret theater] Pittoresque, which Meierkhold was supposed to have run, but then on Meierkhold's urging he turned to the Chamber Theater, proposing to work on the play The Exchange which Meierkhold liked very much, in fact Meierkhol'd was supposed to provide the general scheme [for staging the work]. In doing this Meierkhold invoked the principle of cubes, subsequently used by the artist Yakulov in staging the drama Les Aubes [The Dawn]. But Krol had a conflict with Tairov ${ }^{31}$. 


\section{Keith Tribble}

In his stage design for The Exchange Yakulov chose to juxtapose designs that were conventional in form but dynamic in construction: at stage center a low sloping device consisting of four steps, the left side occupied by a cliff, at far left a weird tree, perhaps a willow, with long branches stretching over the whole stage. A metallic disk of a sun and a sharply drawn zigzag reminiscent of the contour of hills were affixed to a neutral background. Convention and artifice were everywhere: conventional representation of the cliff, the willow, the sun and conventional artifact-veneer, wire and tin. The willow was to reinforce the theme of love, bursts of sunlight suggested eternal happiness. Instead of colors there were projected filters of light. ${ }^{32}$ Indeed, E. Pann had written from Paris back in 1914 that the realization of Claudel's dramaturgy on the stage would require new expressive methods. ${ }^{33}$ Nevertheless, Yakulov was critized for unclearness in resolving the stage program and for the set design being isolated from the play itself, as if he were projecting his own decorative-architectural theme on the work, but Yakulov stated that the modern set designer was no longer content with simply illustrating a play, he had to create something uniquely his own.

Komarovskaia who played the part of Lechy Elbernon has left us this impression of the production in her memoirs:

As a director Tairov gave The Exchange an indiosyncratic reading. He took as his basis the conflict between two world-views, which were born in one and the same civilized country. True to his principle, the director Tairov strove to lay bare in the image of each of the plays' protagonists one dominant trait of character. Thus, in Elbernon he brought to the fore the primeval instinct. The basis for the acting was to demonstrate bare passion, sometimes transforming itself into explicit violation of the norms of social conduct, drunken Elbernon grovelling on the ground, cursing rudely and singing indecent songs. The brilliant fantasy of Aleksandr Iakovlevich Tairov lead him to stray from the author's idea. The formal tasks, both in the contrasts of timbre, and in plasticity, often acquired a self-sufficient meaning. The director's quite arbitrary interpretation turned the flourishing girl Marthe, so full of life and health, into a skinny ugly fanatic conquering all life's adversities 


\section{The Russian Premiere of Claudel's L'Échange}

through unflinching faith in providence. Yakulov shared Tairov's view that in The Exchange raw emotions dominate, so the stage represented primeval chaos made of a heap of various forms. The production of The Exchange in no way corresponded to the mood of the audiences in the first months following the October revolution. ${ }^{34}$

Among the unpublished notes of the theater historian Fevralsky is a bibliography enumerating a dozen notices in the contemporary press about the 1918 Moscow production of The Exchange. ${ }^{35}$ The most detailed document for analysis of the production is the review by Natalia Inber which appeared in the Theatrical Newspaper for 10 March, 1918 from which I will quote at length. While other critics attacked the choice of the play itself as lacking contemporary resonance in post-revolutionary Moscow, Inber criticizes the production for its lacking resonance in the world of Claudel's theater. "The director Tairov and designer Yakulov sealed the stage tight from all sides. No road leads anywhere from this heap of colorless crystals. The sole free and natural movement of an actor is Louis Laine's jump from the cliff. But in order to execute it, he has to wend his way between two pieces of canvas on the left. In the third act Lechy Elbernon appears out of a hole at the footlights. Because of this claustrophobia and lack of a natural exit the image of Louis Laine withdraws into itself, becomes constricted, depreciates.... The image of the tree is extremely important for Claudel. The willow in The Exchange could have become a plastic expression of the grief, undried tears, and tragic fate of the four personnages of the play. Yakulov's willow is an engaging plywood solution and that's it. Yakulov has an immobile tin sun with three plywood rays, but it is not Louis Laine's sun. It should have been a planet of melting gold, like the tragic sun disks in Van Gogh's provençale portraits. The sun of The Exchange is reduced to ashes. It dies out only in the third act and only in the third act could Yakulov's plywood rods have symbolized the last rays of an eternally smoldering love. The arabesque of flat pyramids extending into the rear curtain to the metallic sun, again and again was only a clever architectural discovery. But it was not the mountain ridge whose majestic outline corresponded to the majesty of the drama unfolding at its feet."

The actors acted in a manner sharply differing from the style of the objective world that surrounded them ${ }^{36}$, but clearly approaching the 


\section{Keith Tribble}

intentions of the author. The actor Ferdinandov (two years later he would play Pierre de Craon in the Russian premiere of The Tidings Brought to Mary) embodied his mask less than the others. "Marthe is a heroine of antiquity, such as Kollin, cold in declamation at moments of her highest happiness and inescapable sorrow. The short, monosyllabic, guttural laugh of Komarovskaia, interpreting the role of Elbernon, fully expressed the empty soul of the actress. The statuary character of the personnages was taken to the limit. The actors not only did not live or move on the stage, they just existed appearing out of nowhere. So to the end the author, the actors and the director failed to merge." 37

The critic Iurii Sobolev was even more abrasive in his assessment of the production. The forms of Claudel's drama "naturally call for rejection of the conventional truths of realistic theater, however they in no way require the massive and multilayered suprematist painting of the sets, the thickness of which simply puzzles the spectator." In his view, Tairov's greatest mistake was in this forceable application to the play of a style that was unsuitable for it. The "suprematist" style ${ }^{38}$ lead the actors to declaim their lines in a totally unnatural and unhuman manner and to "jump" acrobatically across the stage. ${ }^{39}$

In the following years The Exchange was occasionally mentioned as a "strong melodrama written in the symbolist manner" 40 , with Thomas Pollock an interesting and original addition to the figure of Tête d'or, a strong powerful personality in the figure of a modern capitalist, both preying and enterprising, but internally resigned..$^{41}$ But no other Russian theaters attempted to stage The Exchange again and the translation by Vilkina and Pann remains unpublished. However, in 1928 Yakulov wrote to Tairov proposing restaging the work: "I have one very interesting plan for a Tragedy-convenient because it calls for only a few actors." 42 This sentence is telling in several ways. It is indicative on the one hand of the grip that Claudel's play held on the set designer's imagination well into the Stalinist era (when there was no longer any real possibility of staging any play by Claudel) and at the same of the purely external interest that the artist showed concerning Claudel's work, his preoccupation with its purely formal aspects.

The original program for the Moscow production of The Exchange Georgii Jakulov. ${ }^{43}$ 


\section{Notes}

1 Actually a previous performance in Russian had occurred earlier in the Ukraine within the bounds of the Russian Empire. In 1915-1916 a production of The Exchange was directed by B. Glagolin at Sinel'nikov's theater in Kharkov in the Ukraine. It is not known what translation was used for the Kiev production, but it is possible that it used the Lunacharsky translation (no longer extant), as Lunacharsky was living in the Ukraine. Sets for this production were designed by Vladimir Vasil'evich Bobritsky (1898-1986). Bobritsky's work as stage designer for this theater in the 1915-1916 season marked his first professional work as an artist; he emigrated to the United States in 1923. See O. L. Leikind, K. V. Makhrov, D. Ia. Severiukhin. Khudozhniki russkogo zarubezh'ia. Biograficheskii slovar' [Artist of Russia Abroad. A Biographical Dictionary] (Sankt-Peterburg: Notabene, 1999), pp. 161-162.

2 Cf. in this regard my articles: "Early Russian Criticism of Claudel (Annensky, Voloshin, Eikhenbaum)" Claudel Studies 24:1-2 (1997): 50-64; "Tvorchestvo Polia Klodelia v otrazhenii russkoi kritiki: o stat'iakh I. Annenskogo, M. Voloshina i B. Eikhenbauma" [The Work of Paul Claudel in the Mirror of Russian Criticism: on the Articles by I. Annensky, M. Voloshin and B. Eikhenbaum] in: Nachalo veka: Iz istorii mezhdunarodnykh sviazei russkoi literatury. Rossiiskaia akademiia nauk. Institut russkoi literatury (Pushkinskii Dom) (Sankt-Peterburg: Nauka, 2000): 234-249.

3 Anatoly Vasil'evich Lunacharsky (1875-1933)—writer, diplomat, politician, statesman. Studied with Avenarius in 1894 at the University of Zurich. where he joined the Russian Social Democratic Labour Party, arrested on his return to Russia in 1896, exiled, returned to Kiev in 1902, arrested by Kerensky in 1917, made Commissar of Education in Lenin's first government (19171929), represented the Soviet Union at the League of Nations in 1930, named Ambassador to Spain just before his death.

4 Anatoly Lunacharsky. "Misticheskaia tragikomediia”. Kievskaia mysl. No. 42 (11 February, 1914).

5 Vsevolod Emil'evich Meierkhol'd (28 January 1874; Penza - 2 February 1940) -actor, student of Stanislavsky with whom he later broke, foremost Russian theatrical director of the twentieth century, extremely influential in Russia and abroad, creator the theory of biomechanics for actors and prime agent for introducing constructivism on the stage. His theatrical troupe toured Europe 


\section{Keith Tribble}

during Claudel's lifetime including notable performances in Paris in 1930 . He was arrested in 1939 and shot in prison a year later.

6 V.E. Meierkhol'd. "Bibliografiia po temam. Avtograf. Rukopis'. 1900-e. 1910e" [Bibliography by subject. Signed manuscript. 1900s. 1910s]. Russian State Archive of Literature and Art (RGALI), fond 998, opis' 1, ed. kh. 842.

7 Vladimir Solov'ev. "Petrogradskie teatry" [The Petrograd Theaters], Apollon, No. 2. 1916, p. 45.

8 Aleksandr Vasilievich Fevralsky. “Obmen. Bibliografiia i vyspiski o p'ese P. Klodelia i spektakle Kamernogo teatra (1930-e - 1960-e gg.)" [The Exchange. Bibliography and Notes about the play by P. Claudel and the production of the Chamber Theater (1930s-1960s)]. RGALI. Fond 2437. Opis' 3. Delo. 169. List 9.

9 Moris Meterlink [Maurice Maeterlinck]. Sochineniia v trekh tomakh. [Works in three volumes]. V perevode L. Vil'kinoi s risunkami khudozhnika N.K. Rerikha. S predisloviiami N. Minskogo, Z. Vengerovoi i V. Rozanova (S.Peterburg: Izd. M.V. Pirozhkova, 1900).

10 Pis'ma Evgeniia Isidorivicha Panna k Meierkhol'du [The letters of Evgeny Isidorovich Pann to Meierkhold], RGALI, fond. 998, opis 1, ed. Sr. 2158, 11. 1-4.

11 Dnevniki pisatelei. No. 1 (March, 1914), p. 55.

12 Georgy Ivanovich Chulkov (1879-1939)_poet, critic, dramatist; closely associated with the symbolists Viacheslav Ivanov (with whom he created the theory of mystical anarchism) and Aleksandr Blok (whose first play "The Fairground Puppet Show" was written at Chulkov's behest).

13 Letter dated 7/20 December 1914 to V.E. Meierkhold. RGALI. Fond 998, op. 1, ed. kh. 2597, list 12 .

14 E. Pann, "Drama vechnosti v tvorchestve Polia Klodelia", Ezhegodnik imperatorskikh teatrov. 1914. Vol. 2, p. 15.

15 E. Pann, "V zashchitu vyrazitel'nogo iskusstva. (Pis'mo iz Parizha)", Maski. No. 6 (1913-1914), p. 44.

16 "Obmen. P'esa v 3-x deist[viiakh] Polia Klodelia. I i II deistvie per[evod] L. Vil'kinoi. IIle deistvie E. Panna. 1918». RGALI. Fond 998, opis' 1, ed. khr. 130 (typescript with handwritten corrections by the translators); Klodel'. “Obmen". 1918. Fond 2030, opis' 1, ed. khr. 288 (typescript with handwritten emendations). 


\section{The Russian Premiere of Claudel's L'Échange}

17 “Obmen". P'esa v 30x deistviiakh Polia Klodel'. 1 I 2 deistviia perev. L. Vil'kinoi. 3-e perev. Panna. V14450. Perep. No. 277 III O-19. Russkoe Teatral'noe Obshchestvo [Moscow].

18 See, in particular, André Levinson on dance; Writings from Paris in the twenties, edited with an introduction by Joan Acocella and Lynn Garafola (Hanover, N.H.: Wesleyan University Press; University Press of New England, 1991).

19 Andre Levinson. "Teatr. Otryvok iz tragedii Polia Klodelia >Mena" [Theater. An Excerpt from Paul Claudel's Tragedy "The Exchange"], Zhizn' iskusstva. No. 5 (2 November, 1918), p. 3. Of particular interest is Levinson's decision to translate the title of Claudel's drama by the Russian word "mena" rather than the more commonly used "obmen". The word "Mena" used most frequently in jurisprudential parlance indicates "an agreement according to which an exchange of one property for another takes place between two parties". From 1910 Levinson was professor of French literature at the University of Saint Petersburg and in emigration was later to become professor at the Sorbonne in Paris.

20 Alisa Koonen, "Stranitsy iz zhizni" [Pages from a life], Teatr. 1968. No. 3 [March], p. 103. Alisa Koonen was Tairov's wife and, although she did not act in the production of L'Échange, she later created the part of Violaine on the stage in the Russian premiere of L'Annonce faite à Marie (her acting text for the part of Violaine is preserved at the State Bakhrushin Theatrical Museum in Moscow). Her memoirs were also published in book form: Stranitsy zhizni (Moscow: Iskusstvo, 1975), where the same passage is repeated on p. 242. Meierkhol'd had originally hoped that Koonen would portray Marthe in his production of The Exchange (cf. his letter of late December 1917 to Tairov in V.E. Meierkhol'd. Perepiska, p. 193).

21 V.E. Meierkhol'd. Perepiska. 1896-1939 [Correspondence. 1896-1939]. Eds. V. P. Korshunova, M. M. Sitkovetskaia, Yu. A. Zavadsky (Moscow: Iskusstvo, 1976), p. 192.

22 V.E. Meierkhol'd. Perepiska, p. 189. The letter is dated Petrograd, 13 September 1913. According to Meierkhol'd's letters it appears that Evgeny Pann re-entered his life at this time and fine-tuned the translation he and Vil'kina had written five years earlier.

23 A. Ia. Tairov. Zapiski rezhissera. Stat'i. Besedy. Rechi. Pis'ma [A Director's Notes. Articles. Conversations. Speeches. Letters]. Eds. P. Markov, Iu. Golovashenko. Moscow: Vserossiiskoe teatral'noe obshchestvo, 1970), pp. 18, 106, 511 . 


\section{Keith Tribble}

24 Imaginism was an avant-garde literary group (1919-1927) headed by Vadim Shershenevich and including the poets Esenin, Mariengov, Ivnev and the painters Erdman and Yakulov; the French artist Ferdinand Léger also belonged to the group. The movement was designed to replace futurism (with which it actually had a lot in common) by representing life through the image and the rhythm of images and writing in free verse. The group was blasted and marginalized by the Soviet literary establishment and its literary production (consisting essentially of small printings) only began to be reprinted after the demise of the Soviet Union. Like futurism, imaginism was influenced by the theories of the Italian poet Marinetti.

25 L. Nikulin. “Trekhmernost' i imazhinizm”, Vestnik teatra. 1918. No. 55, p. 7.

26 Charles Vildrac, Georges Duhamel, Teoriia svobodnogo stikha [The Theory of Free Verse], perevod Vadima Shershenevicha (Moscow: Imazhinisty, 1920).

27 The memoirs of Shershenevich "Velikolepnyi ochevidets. Poeticheskie vospominaniia 1910-1925» [Magnificent Eyewitness. Poetic memoirs 19101925], unavailable throughout most of the Soviet era, were finally published during the perestroika period in the book by S. V. Shumikhin and K. S. Yuriev, Moi vek, moi druz'ia i podrugi. Vospominaniia Mariengofa, Shersehnevicha $i$ Gruzinova (Moscow: Moskovsky Rabochii, 1990), p. 417-646, on Claudel see especially p. 637.

28 V. E. Meierkhol'd, Perepiska, p. 191.

29 R. Khidelkel', "O trekh khudozhnikakh Kamernogo teatra” [On three artists of the Chamber Theater], Iskusstvo (1971), No 5, p. 43.

30 Georgy Aleksandrovich Krol' ((1893-1943)-film director, protégé of Meierkhol'd who later emigrated first to Berlin where he directed a cabaret theater, then later to Paris. In Decembe 1917 Meierkhol'd wrote to Tairov: "Permit me to present to you my student from directing class and now my assistant Goergy Aleksandrovich Krol'. He is bringing you my plans for staging The Exchange by Claudel. He will deliver to you two copies of the play. Give one of them immediately to be copied role by role [...] I ask you to reach an agreement with G. A. Krol' about my honorarium (a percentage of the house?). I will be paying him out of my honorarium." (Cf. V. E. Meierkhol'd, Perepiska, p. 193.

31 Aleksandr Vasil'evich Fevralsky. “Obmen. Bibliografiia i vyspiski o p'ese P. Klodelia i spektakle Kamernogo teatra (1930-e - 1960-e gg.)" [The Exchange. Bibliography and Notes about the Play by P. Claudel and the production of 


\section{The Russian Premiere of Claudel's L'Échange}

the Chamber Theater (1930s-1960s)]. RGALI. Fond 2437. Opis'3. Delo. 169. List 9.

32 Semen Aladzhalov. Georgii Yakulov (Erevan: Armianskoe teatral'noe obshchestvo, Institu iskusstv Akademii nauk Armianskoi SSR, 1971), p. 63-65.

33 E. Pann, "V zashchitu vyrazitel'nogo iskusstva "Pis'mo iz Parizha)", p. 43.

34 N.I. Komarovskaia. Vidennoe i perezhitoe. Iz vospominanii aktrisy [Seen and experienced. From the memoirs of an actress]. Leningrad-Moscow: Iskusstvo, 1965, pp. 129-131.

35 Teatralnaia gazeta [Moscow]. No. 6. P. 14, 16-22, 3-32; Teatralnaia gazeta [Moscow]. No. 2-3 (14 January, 1918); Teatralnaia gazeta [Moscow]. No. 5 (28 January, 1918); Teatralnaia gazeta [Moscow]. No. 7 (26 February, 1918); Teatralnaia gazeta [Moscow]. No. 10 (10 March, 1918); Teatralnaia gazeta [Moscow]. 20 February, 1918; Teatralnaia gazeta [Moscow]. 5 March, 1918; "Obmen v Kamernom". No. 13 (31 March, 1918), p. 7-8; Teatralnaia gazeta [Moscow]. No. 35-36 (11 November, 1918); Teatralnaia gazeta [Moscow]. No. 37-38 (25 November, 1918); "Libretto Obmen". Teatr. No. 2089. 1918; Iurii Sobolev. "Stil Pittoresk". Teatr. No. 2995; "Khronika”. Rampa i zhizn'. No. 4. 1918 , p. 10.

36 Meierkhol'd had written to Tairov in December 1917: "For the role of the Banker appoint an actor who can deliver his speeches quickly and with a light figure, even though heavy-set. For the main male part a handsome actor is needed, flexible, but not a poseur and without a trace of sugariness." (V.E. Meierkhol'd, Perepiska, p. 193).

37 Natal'ia Inber, “>Obmen' Polia Koledia" [Paul Claudel's The Exchange], Teatral'naia gazeta [Moscow]. 1918. No. 11, pp. 6-8.

38 The critic is referring to the systematic school of non-objective abstract painting developed by Kasimir Malevich around 1913. Suprematism was characterized by eliminating all superfluity and emphasizing the supremacy of pure feeling over objectivity in art. Although Malevich felt it had run its course by 1919, the style remained dominant in the work of Rozanova, Rodchenko, Kliun and Puni. Some critics had dubbed certain productions (Ekster's "Salome", Vesnin's "The Tidings Brought to Mary") at Tairov's Chamber Theater as suprematism on the stage.

39 Iurii Sobolev, "Stil" Pittoresk" [The Style of the Picturesque], Teatr. No. 2985 (March-April, 1918), pp. 3-4. The title of Sobolev's review derives from the name of a Moscow cabaret where Iakovlev had previously worked. 


\section{Keith Tribble}

40 A.S. "Teatr. Parizhskie teatry" [Theater. The Parisian Theaters]. Sovremennyi zapad. 1923. Vol. 2, pp. 239-240.

41 Vadim D'iakonov, "Pol' Klodel”" [Paul Claudel] Kul'tura teatra. No. 5 (1921), p. 9.

42 Letter dated 8 September 1928 from Tiflis (Georgia), cf. E.M. Kostina, "Iz episteliarnogo i literaturnogo naslediia Georgiia Yakulova" [From the epistolary and literarary remains of Georgy Yakulov]. In: Puti i pereput'ia. Materialy $i$ issledovaniia po otechestvennomu iskusstvu XX veka (Moscow: Rossiiskaia Akademiia Khudozhestv, 1995), p.157.

43 There is also a reproduction of one of Yakulov's set designs in the book: Abram Efros. Kamernyi teatr i ego khudozhniki 1914-1934 [The Chamber Theater and its artists. 1914-1934]. (Moscow: Vserossiskoe teatral'noe obshchestvo, 1934), p. 202. 